\title{
TODELLISUUS KUTSUU, KUULEEKO PRAGMATISTI?
}

Tero Piiroinen: Margaret Archerin dualistinen yhteiskuntateoria - kriittinen tarkastelu pragmatistisesta näkökulmasta. Turun yliopisto, Koulutussosiologian tutkimuskeskuksen raportti 79, 2013.

Helsingin yliopistossa on viime vuosina ollut havaittavissa lisääntynyttä kiinnostusta pragmatismia kohtaan. Vastaavaa kiinnostusta on virinnyt myös Turun yliopistossa, jossa kasvatussosiologi Osmo Kivinen on ahkeroinut oppilaidensa kanssa pragmatismiin liittyvien metodologis-filosofisten kysymysten parissa varsinaisen päivätyönsä ohessa. Jos hieman yksinkertaistaa asioita, niin voinee väittää, että helsinkiläisten pragmatismi on peirceläistä, kun taas turkulaiset nojaavat Richard Rortyyn. Ainakin Turussa syksyllä 2013 väitelleen Tero Piiroisen väitöskirja ${ }^{1}$ asemoituu selkeästi rortylaisten leiriin, jota voi kutsua antirealistiseksi, koska se pyrkii esittämään, että uskomuksiamme ja näiden uskomusten kohteita ei voida erottaa toisistaan. Piiroisen monografian varsinainen aihe on kuitenkin brittiläisen sosiologin ja yhteiskuntateoreetikon Margaret Archerin realistinen yhteiskuntaontologia ja siihen liittyvä ihmiskäsitys. Erityishuomion kohteena on se, miten Archer kuvaa toiminnan ja rakenteen välisen suhteen dualistiseksi. Piiroinen itse on vannoutunut antidualisti, joten Archerin näkemyksiin suhtaudutaan kirjassa erittäin kriittisesti. Kritiikin mittapuuna Piiroinen käyttää luentaansa pragmatismista, jota on höystetty sekä rortylaisin että ehkä hieman yllättäen myös käyttäytymistieteellisin maustein. Rorty ja käyttäytymistieteiden nykytuulahdukset eivät nimittäin ole niitä kaikista ilmeisimpiä petikumppaneita.
Piiroinen esittelee ansiokkaasti, miten Archerin yhteiskuntateorian keskeiset oletukset juontavat juurensa kriittisestä realismista. Kriittisen realismin pääidea on niin sanottu taso-ontologia, jossa todellisuus jakautuu tasoihin sen perusteella, missä määrin kullakin tasolla on itsenäistä kausaalista vaikuttavuutta. On helppo yhtyä Piiroisen väitteeseen, jonka mukaan Archer vie ajatuksen erillisistä ontologisista tasoista liian pitkälle. Archerin yhteiskuntateoriassa tämä taso-oletus näkyy etenkin toiminnan ja yhteiskuntarakenteiden välisen suhteen tarkastelussa. Tämän suhteen tarkastelu edellyttää Archerin mielestä niin sanottua analyyttista dualismia, jossa toiminta ja rakenteet erotetaan toisiinsa palautumattomiksi ontologisiksi tasoiksi. Rakenteet vaikuttavat tässä katsannossa yksilöiden toimintaan ennen kaikkea sitä kautta, että yksilöt reflektoivat ja asemoivat elämänprojektejaan suhteessa rakenteiden asettamiin rajoitteisiin ja mahdollisuuksiin.

Tällainen näkemys olettaa, että rakenteiden vaikutus toteutuu ainakin hyvin pitkälti yksilöreflektion kautta, vaikka eivät rakenteet pelkkään reflektioon palaudukaan, sillä tällainen "palauttaminen" olisi kriittiselle realismille vierasta reduktionismia. Piiroisen mukaan yhteiskuntarakenteiden uusintamisen (kuten myös niiden muuttumisen) tulee näkyä ihmisten keskinäisessä toiminnassa - ennen kaikkea heidän tavanmukaisessa toiminnassaan. Tavanmukaisen (babitual) toiminnan roolin korostaminen yhteiskuntarakenteita konstituoivana tekijänä on tuttua jo klassisilta pragmatisteilta. On kuitenkin eri asia, liittyykö johonkin yhteiskuntarakenteeseen esimerkiksi lakiin kirjattuja muodollisia sääntöjä tai 
vaikka arkkitehtuurin kautta manifestoituvia tilallisia järjestelyjä, vai onko kyse puhtaasti tavanmukaisista toiminta-alttiuksista. Edellisten muuttaminen on yleensä huomattavasti hankalampaa kuin puhtaasti tavanmukaisten toimintamallien, vaikka tavatkin usein istuvat tiukassa. Piiroisen käsittelyssä nämä yhteiskuntarakenteiden eri aspektit palautuvat tavanmukaisiin toiminta-alttiuksiin, mitä voi pitää turhan suppeana näkökulmana asiaan.

Piiroinen ei itse asiasta mainitse, mutta muiden kriittisten realistien tapaan Archer liioittelee mekanismien roolia kausaaliselityksissä yhteisriippuvuuksien havaitsemisen kustannuksella. On toki selvää, että mekanismi(e)n osoittaminen tekee kausaaliselityksestä paljon rikkaamman ja vakuuttavamman kuin pelkän yhteisvaikutuksen paikantaminen, mutta kyllä kausaalisuhteen olemassaolosta voidaan esittää oletuksia, vaikka varsinaista mekanismia ei tunnettaisikaan. Kaikessa empiirisessä tutkimuksessa joudutaan kuitenkin olemaan väistämättä realisteja ainakin jossain määrin, sillä teorian avulla yleensä postuloidaan mekanismi, joka ei sellaisenaan ole aineistossa suoraan havaittavissa. Piiroinen toteaa itse olevansa ennen kaikkea empiristi ja instrumentalisti, mutta samaan aikaan hän kuitenkin sanoo pitävänsä mekanismeilla selittämisen ideaa hyödyllisenä. Epäselväksi jää, missä määrin empirismi ja instrumentalismi todella voidaan yhdistää mekanismeilla selittämisen ideaan, mikäli jälkimmäinen idea edellyttää sitä, että mekanismit eivät palaudu dataan (niin kuin kriittiset realistit väittävät). Näin ollen on epäselvää, mistä mekanismeissa Piiroisen mielestä oikein on kyse.

Piiroinen esittelee myös Archerin niin sanotut refleksiivisyystyypit, jotka kuvaavat ihmisten vaihtelevia asennoitumistapoja suhteessa yhteiskunnallisten rakenteiden asettamiin mahdollisuuksiin ja rajoitteisiin. Yksilön refleksiivisyystyyppi varioi pääasiassa sen mukaan, missä määrin yksilön omat, sisäiset pohdiskelut nojaavat muilta toimijoilta saatavaan palautteeseen. Piiroinen kritisoi tällaista yksilöreflektion suurta roolia korostavaa näkemystä siitä, että se olettaa yksilöiden päässä sijaitsevan pienen homunculuksen - eräänlaisen tietoisuuden keskusvalvomon - ja sen, että yksilöt ovat itselleen läpinäkyviä. Tämä homunculus-oletus näkyy Archerin refleksiivisyystyyppien tutkimusotteessa siinä, että se keskittyy ohjelmallisesti selvittämään syvähaastattelujen avulla rakenteiden vaikutusta yksilöiden elämänkohtaloihin; vain yksilöillä itsellään kun on suora pääsy heidän omaan mieleensä Archerin mukaan. Piiroinen erittelee osuvasti tällaiseen käsitykseen liittyviä monenmoisia ongelmia muun muassa Daniel Dennettiin nojaten. Reflektiokyvyn erottaminen ruumiillisesta toiminnasta omaksi erilliseksi tasokseen sotii myös klassisten pragmatistien toiminnan tavanmukaisuuden ajatusta vastaan. Pragmatistien käsissä toimintatavat nimittäin sisältävät myös reflektointikyvyn siemenet; reflektio nimittäin nojaa aina toimintatapoihin - ja voi paradoksaalisesti myös muuttua tavanomaiseksi. Ihmisillä tuskin on sellaista suoraa pääsyä omaan mieleensä kuin Archerin teoria näyttää olettavan, sillä myös omaa mieltä tulee tulkita erilaisten merkkien kautta.

Keskeinen ongelma Piiroisen väitöskirjassa on se, että hän ei asemoi tekstin alussa omaa näkökulmaansa. Hän ei oikeastaan edes ilmoita, mikä hänen tutkimusongelmansa on. Archerin käsitysten ja niistä esitettyjen kritiikkien käsittely on pääosin varsin pätevää ja oppineisuutta osoittavaa, mutta lukija joutuu odottamaan liian pitkään ennen kuin Piiroisen oma kanta ja tarkastelukulma kulloiseenkin kysymykseen selviävät. Alkuluvussa todetaan, että Archerin näkemyksiä eritellään teoriabistoriallisen analyysin keinoin. Archerin teorian taustaa ja sen kehityskaarta käsitelläänkin jonkin verran, mutta Piiroisen tulokulmaa on hyvin vaikea mieltää varsinaisesti teoriahistorialliseksi. Kirjassa käytetään mittapuuna Archerin käsityksille täysin vastakkaista näkemystä, niin sanottua antidualismia (toiminta ja rakenne saman asian eri puolina), ja sen avulla pyritään osoittamaan Archerin teorian ongelmakohtia 
- ilman varsinaista käsiteltyjen ideoiden historiallista kontekstualisointia, josta teoriahistoriallisessa luennassa yleensä on kyse.

Käytännössä Piiroinen pitää Archerin näkemyksiä lähtökohtaisesti niin ongelmallisina, ettei niistä juuri ole opittavaa muutoin kuin negatiivisessa mielessä, varoittavana esimerkkinä, jonka korvaavaksi oppirakennelmaksi tarjotaan antidualismia ja pragmatismia. Piiroinen myöntää, että pragmatismin sisällöstä on olemassa erilaisia tulkintoja, mutta varsinainen reflektio siitä, millaiseen tulkintatraditioon hänen näkemyksensä pragmatismista liittyy, on työssä vähäisessä roolissa. Ennen kaikkea lukija jää kaipaamaan pohdintaa siitä, miksi tietty tulkintatraditio on valittu: minkälaisen maailman tämä näkökulma avaa ja minkä suhteen se mahdollisesti on sokea - tai ainakin vahvasti likinäköinen.

Piiroinen esittää pragmatistien, etenkin John Deweyn ja G. H.Meadin, olleen antidualistisia ajattelijoita, jotka pyrkivät osoittamaan yksilöiden ja rakenteiden vastakkainasettelun hedelmättömyyden. Tähän tehtävään molemmat herrat sopivatkin epäilemättä oikein hyvin. Deweya käytetään käsikirjoituksessa pitkin matkaa mittapuuna Archerin näkemysten ongelmakohdille, mutta pikkuhiljaa myös Richard Rorty -vaikutteet alkavat paistaa läpi, mikä näkyy kielikeskeisessä semiotiikassa, tietynlaisessa näkemyksessä kielestä ja yleisessä antirealistisessa asenteessa. Tähän vaikutusyhteyteen liittyy Piiroisen esittämä semanttisen realismin kritiikki ja semanttisen holismin puolesta puhuminen. Jälkimmäinen kanta pyrkii joko kiistämään, että kieli ylipäätään olisi viittaussuhteessa kielen ulkopuoliseen todellisuuteen tai ainakin väheksymään viittaussuhteiden roolia kielen omaksumisessa. Piiroinen väittää kaikkien antidualistien kannattavan semanttista holismia. Pragmatismin klassikoista sen paremmin Peirce kuin Mead eivät kuitenkaan istu ongelmattomasti Piiroisen luvalla sanoen dualistiseen semiotiikkaan, jossa tulisi valita joko kieli merkkijärjestelmänä tai kieli viittaussuhteiden kokonaisuutena.
Piiroisen valitseman semioottisen näkökulman haittapuoli on, että se unohtaa saussurelaisessa hengessä muut kuin kielelliset ja symboliset "merkkiytymisen" prosessit. Piiroisen esityksestä saakin sen kuvan, että kieli on puhtaasti arbitraaristen ja symbolisten, kielen sisäisten viittaussuhteiden kokonaisuus. Tämä on erikoista - ei vain siksi, että se sotii suoraan Peircen pragmatismia vastaan, vaan myös siksi, että monin paikoin Piiroinen korostaa näkökulmansa olevan darwinistinen. On hyvin vaikea kuvitella mitään evolutiivista syytä, miksi tällainen mukamas omalakinen ja arbitraarinen ilmiö olisi koskaan ilmaantunut maailmaan - tai miten pieni lapsi kykenisi ikinä oppimaan kieltä, jos ei juuri toiminnan kontekstiin liittyvien viittaussuhteiden kautta.

Hieman toisenlaisen, nimenomaan darwinilaisen perspektiivin kieleen tarjoaa esimerkiksi G. H. Mead kuuluisassa koiratappeluesimerkissään, jossa koira murisee toiselle koiralle. Murina-reaktion laukaissut koira ei Meadin mukaan säikähdä murinaa sinällään, vaan murisemisen merkitystä - sitä, että se viittaa hyökkäyksen mahdollisuuteen. Tässä esimerkissä, toisin kuin kielessä, on toki kyse vain subjektiivisista merkityksistä, sillä ne eivät ole intersubjektiivisesti yhteisiä molemmille koirille. Kannattaa kuitenkin huomata, että myös kielessä on Meadin mukaan kyse "vokaalisista eleistä", ei toiminnasta irrallisesta järjestelmästä, josta viittaussuhteet kielen ulkopuoliseen maailmaan kokonaan puuttuisivat. Kieli kun on hänen mukaansa kehittynyt eleiden korvikkeeksi,"helpottamaan ja koordinoimaan yhteistoimintaa", kuten Erkki Kilpinen on Mead-luennassaan todennut.

Ja vaikka viittaussuhteen voisikin "selittää vain kielellisesti" - kuten Piiroinen toteaa tästä ei seuraa, että referenssin voisi ymmärtää vain tietyn kielen sisäisenä asiana. Näin on vain ja ainoastaan, jos sitoudutaan käsitykseen kielestä niin sanottuna universaalina väliaineena, jonka ulkopuolelle emme koskaan voi asettua. Pragmatismin klassikoista etenkin Peirce edusti täysin vastakkaista kantaa, jota Jaakko 
Hintikka on kutsunut käsitykseksi kielestä kalkyylina. Tämän näkemyksen mukaan kielen ja maailman välistä suhdetta voidaan aivan hyvin tarkastella muun muassa siitä syystä, että on olemassa useita eri kieliä eikä metakielen rakentaminenkaan ole poissa laskuista. Kielitematiikan käsittely olisi kaiken kaikkiaan edellyttänyt Piiroiselta nykyistä syvällisempää otetta - tai vaihtoehtoisesti pidättäytymistä koko tematiikan käsittelystä.

Piiroisen pragmatismi päätyy vieroksumaan kaikenlaisia ontologisia olettamuksia. Hänen retorisena strategianaan on osoittaa, että Archer tekee liian voimakkaita ontologisia olettamuksia - siispä ontologia voidaan yleisesti ottaen hylätä tarpeettomana tai jopa haitallisena. Piiroinen kun olettaa, että ontologiset olettamukset ovat väistämättä sellaisia, joiden kohteiden esitetään olevan ihmisistä riippumattomia ja täysin muuttumattomia. Oli Archerin ontologisista olettamuksista mitä mieltä tahansa, ei ole mitään välttämätöntä syytä määritellä ontologiaa opiksi muuttumattomasta todellisuudesta. Kannattaa muistaa, että klassisten pragmatistien on väitetty nimenomaan kääntäneen klassisen filosofian lähtökohdan ylösalaisin - Darwinin vaikutuksesta johtuen - niin, että filosofiassa tulee heidän mukaansa lähteä liikkeelle ontologiasta eikä epistemologiasta käsin. Halusimme tai emme, teemme väistämättä ontologisia olettamuksia, mutta ne ovat nimenomaan olettamuksia, jotka alistamme falsifioinnille niin tiedeinstituution käytänteissä kuin arkipäiväisissä toimissamme (jälkimmäisissä tosin hyvin valikoivasti ja vaihtelevalla menestyksellä), eikä näitä olettamuksia käytännössä kuvitella ikuisiksi ja muuttumattomiksi. Uskonnot ovat luultavasti poikkeustapauksia siinä, että ne yleensä esittävät esittävänsä muuttumattomia ontologisia olettamuksia, vaikka käytännössä myös uskontojen ontologiset oletukset muuttuvat aikojen saatossa (usein kovin hitaasti ja hyvin vastahankaisesti).

Piiroinen hyljeksii ontologiaa sillä perusteella, että Deweyn mukaan tietävää subjektia ja tiedon kohdetta, objektia, ei voida erottaa mutkattomasti toisistaan. Tässä on toki perää siinä mielessä, että tietäminen tapahtuu aina jostain näkökulmasta käsin; vastataanhan esimerkiksi tieteellisissä tutkimuksissakin yleensä aina johonkin tutkimuskysymykseen jonkin sellaisen datan avulla, joka on valittu ja rakennettu niin, että se ylipäätään mahdollistaa vastauksen saamisen. Tietämistä lieneekin ylipäätään järkevä ajatella kysymyksiin vastaamisena sekä kysymysten ja vastausten toisiinsa limittyvänä kokonaisuutena - eräänlaisena koko ajan täydentyvänä ja korjautuvana ristisanatehtävänä, Susan Haackin viljelemää metaforaa käyttääkseni. Toisin kuin Piiroinen väittää, tällainen näkemys ei kuitenkaan tarkoita sitä, että data ei saisi tutkimuksessa lainkaan omaa, taustateoriaan palautumatonta roolia. Mikäli data todella palautuisi kulloiseenkin taustateoriaan, niin tällöin voisimme kaikki ryhtyä nojatuoliteoreetikoiksi tai käsiteanalyytikoiksi!

Piiroisen kritiikki Archerin esisosiaalista käytäntökäsitystä kohtaan sen sijaan on pääosin osuvaa, sillä Archer väittää, että artefakteja opittaisiin käsittelemään ja käyttämään vain ja ainoastaan esisosiaalisten ruumiintuntemusten varassa ja että itsetietoisuudessa on kyse pelkästään tällaisista esisosiaalisista ruumiintuntemuksista. Piiroinen sivuuttaa silti yksilöiden ylisosiaalistamisen ongelman - josta Archer aiheellisesti kantaa huolta - hieman liian yksioikoisesti. Nyky-yhteiskuntateoriaa seuratessaan on vaikea olla huolestumatta siitä, miten paljon alalla vilisee erilaisia, niin sanottuja tyhjä taulu -teorioita, joissa yhteiskunta kirjoittaa sanottavansa yksilön mieleen (tämänkään lehden sivuilla tällaiset näkemykset eivät valitettavasti ole vieraita). Piiroisen aikalaisdiagnoosin $\mathrm{mu}-$ kaan länsimaisilla ihmisillä on vahva kokemus yksilöllisyydestä vain ja ainoastaan siksi, että meidät on sosiaalistettu yksilöllisyyden ideaan. Epäilemättä yksilöllisyyden ja yhteisöllisyyden ilmenemismuotoja säännellään moraalin kautta eri tavoin eri aikoina ja eri kulttuureissa. Silti esimerkiksi Mead piti yksilöllisyyden kokemusta minuuden konstituutioon kuuluvana 
piirteenä eikä se näin ollen välttämättä ole riippuvainen länsimaisista ideoista niin vahvasti kuin Piiroinen esittää. Lisäksi myös nykyinen kognitiotiede - johon Piiroinen muutoin viittaa hyväksyvästi - on osoittanut, että ihmiset ovat luonnostaan dualisteja sikäli, että mielen ja ruumiin koetaan olevan eri asioita. Tämä ei luonnollisestikaan tarkoita, että mieli ja ruumis oikeasti olisivat toisistaan irrallisia entiteettejä, vaan että tämä on ihmisille tyypillinen kokemus asiasta.

Lopuksi todettakoon, että Piiroinen kirjoittaa vaikeistakin asioista melko selkeästi ja niin, että lukijan kiinnostus pysyy hyvin yllä. Tekstiin on paikoin kuitenkin päässyt livahtamaan turhan puhekielisiä ilmaisuja ja kieli-

\section{VIITTEET}

1. Toimin Risto Heiskalan kanssa sekä Piiroisen väitöskirjan esitarkastajana että hänen toisena vastaväittäjänään. Kiitänkin Ristoa yhteistyöstä. oppivirheitä. Olen itse aiemmin ollut melko vakuuttunut Deweysta innoituksensa saaneen pragmatismin käyttökelpoisuudesta yleisenä filosofisena viitekehyksenä, joka mahdollistaa yhteiskunta- ja käyttäytymistieteiden vuoropuhelun. Piiroisen kirjan luettuani olen kuitenkin alkanut huolestua siitä, että Deweyn ajatuksissa on myös vakavia puutteita, sillä näköjään niistä voidaan johtaa sellaisia antirealistisia päätelmiä kuin Piiroinen tekee. Piiroisen kirja saikin minut pohtimaan ennen kaikkea pragmatismin ongelmia, ei sen ansioita - mikä on, pahoin pelkään, varmasti vastoin kirjoittajan intentioita.

- ANTTI GRONOW 